\title{
Hubungan Peran Keluarga Dengan Pengendalian Kadar Gula Darah Pada Pasien Diabetes Melitus di Wilayah Kerja Puskesmas Pauh Padang
}

\author{
Honesty Putri ${ }^{a}$, Fitra Yeni ${ }^{a}$, Tutwuri Handayani ${ }^{\mathrm{b}}$ \\ ${ }^{a}$ Fakultas Keperawatan Universitas Andalas \\ ${ }^{b}$ Dinas Kesehatan Kota Padang \\ Korespondensi: Honesty Putri \\ E-mail: Honesty_putri9@yahoo.co.id
}

\begin{abstract}
Diabetes mellitus is a chronic metabolic disease or disorder with multietiologi characterized by high blood sugar levels (hyperglycemia). Diabetes mellitus can not be cured but can be controlled by regulating blood sugar levels. One of important factor in controlling blood sugar levels is the family role. The purpose of this study was to determine relation between family role with blood sugar levels in diabetes mellitus patients at the working area of Pauh Health Center Padang 2013. The study was a descriptive analytic with cross sectional approach. were taken with simple random sampling technique. Data were analyzed using univariate descriptive statistical form frequency distributions and bivariate analysis performed by chi-square test with a significance level of $\alpha 0.05$. The results showed $53.3 \%$ of respondents had an unfavorable role of the family in patients with diabetes mellitus, $57.8 \%$ with abnormal blood sugar levels. The results of the bivariate analyzes indicate that there is a significant relationship between the role of family ties with the blood sugar levels in patients with diabetes mellitus $(p<0.05)$. Based on the results, the role of the family has a role in controlling blood sugar levels. Therefore expected to increase family participation in care and to motivate patients with diabetes mellitus in controlling blood sugar levels so that blood sugar levels under controlled conditions.
\end{abstract}

Key words: Family role, Diabetes Mellitus, Blood Sugar Control

\begin{abstract}
Abstrak: Diabetes melitus merupakan suatu penyakit atau gangguan metabolisme kronis dengan multietiologi yang ditandai dengan tingginya kadar gula darah (hiperglikemia). Diabetes Melitus tidak dapat disembuhkan tetapi dapat dikontrol dengan mengatur kadar gula darah. Salah satu faktor penting dalam mengontrol kadar gula darah adalah peran keluarga. Tujuan penelitian ini adalah untuk mengetahui hubungan peran keluarga dengan pengendalian kadar gula darah pada pasien Diabetes melitus di Wilayah kerja Puskesmas Pauh Padang tahun 2013. Jenis penelitian ini adalah deskriptif analitik dengan pendekatan cross sectional. Pengumpulan data dilakukan 6 maret - 17 maret 2013. Data dikumpulkan dengan kuesioner dan pemeriksaan kadar gula darah. Sampel berjumlah 90 responden yang diambil dengan teknik simple random sampling. Data dianalisa secara univariat menggunakan stastistik deskriptif berupa distribusi frekuensi dan analisa bivariat dilakukan dengan uji chi-square dengan tingkat kemaknaan $\alpha 0,05$. Hasil penelitian menunjukkan 53,3\% responden memiliki peran keluarga yang kurang baik pada pasien diabetes melitus, 57,8 $\%$ dengan kadar gula darah tidak normal. Hasil analisis bivariat menunjukkan bahwa terdapat hubungan yang bermakna antara hubungan peran keluarga dengan kadar gula darah pada pasien diabetes melitus $(p<0,05)$. Berdasarkan hasil penelitian didapatkan peran keluarga mempunyai peranan dalam pengendalian kadar gula darah. Oleh karena itu diharapkan keluarga meningkatkan keikutsertaan dalam merawat dan memotivasi pasien diabetes melitus dalam mengendalikan kadar gula darah supaya kadar gula darah dalam keadaan terkendali.
\end{abstract}

Kata kunci: Peran Keluarga, Diabetes Melitus, Pengendalian Kadar Gula Darah

\section{PENDAHULUAN}

Umur Harapan Hidup Indonesia tahun 2013 telah menetapkan angka harapan hidup sebesar 70 tahun. Sedangkan umur harapan hidup di Sumatera Barat itu sendiri sebesar 71 tahun. Penambahan usia harapan hidup menunjukan telah terjadinya peningkatan kemampuan penduduk dalam memperbaiki kualitas hidup dan lingkungan. Disisi lain akan lebih banyak penyakit kronik yang akan di derita 
masyarakat (Badan Statistik Indonesia, 2012).

Penyakit kronik adalah suatu kondisi dimana terjadi keterbatasan pada kemampuan fisik, psikologis atau kognitif dalam melakukan fungsi harian atau kondisi yang memerlukan pengobatan khusus dan terjadi dalam beberapa bulan (Schloman, et dalam Potts, 2007). Salah satu penyakit kronis adalah penyakit diabetes melitus. Diabetes melitus adalah kondisi dimana tubuh memiliki kadar gula darah yang sangat tinggi (Aurora, 2009).

Sementara menurut WHO, 2006 diabetes mellitus didefinisikan sebagai suatu penyakit atau gangguan metabolisme kronis dengan multietiologi yang ditandai dengan tingginya kadar gula darah disertai dengan gangguan metabolisme karbohidrat, lipid dan protein sebagai akibat insufisiensi fungsi insulin. Insufisiensi fungsi insulin dapat disebabkan oleh gangguan atau defisiensi produksi insulin oleh sel-sel beta Langerhans kelenjar pankreas, atau disebabkan oleh kurang responsifnya selsel tubuh terhadap insulin. Diabetes mellitus terjadi karena ketidakmampuan tubuh mengubah makanan menjadi energi (Aurora, 2009).

Mengingat diabetes melitus adalah penyakit selama hidup, maka pengawasan dan pemantauan dalam penatalaksanaan diabetes melitus pada setiap saat menjadi penting. Oleh karena itu maka penatalaksanaan penderita diabetes melitus tidak dapat sepenuhnya diletakkan pada pundak dokter dan klinis saja. Dalam hal ini peran penderita diabetes melitus dan keluarganya sangat diperlukan khususnya dalam pengontrolan kadar gula darah pada penderita diabetes melitus ke dalam situasi sehat atau paling tidak mendekati normal (Waspadji, 2009).

Beberapa upaya yang bisa dilakukan untuk mencapai tujuan mengontrol kadar gula darah adalah dengan kombinasi antara pengaturan diit, olah raga, obat anti diabetik, penilaian kontrol dan pendidikan. Keberhasilan penatalaksanaan diabetes melitus juga ditentukan oleh peranan aktif dari penderita diabetes melitus sendiri, keluarganya dan masyarakatnya dalam pengontrolan kadar gula darah, pencegahan komplikasi akut maupun kronik (Asdie, 2000).

American Diabetes Association, 2006 mengatakan bahwa perencanaan pengelolaan diabetes harus dibicarakan sebagai teraupetik antara pasien dan keluarganya. Pasien harus menerima perawatan medis secara terkoordinasi dan integrasi dari Tim kesehatan, sehingga keluarga menyadari pentingnya keikutsertaan dalam perawatan penderita diabetes melitus agar kadar gula darah penderita dapat terkontrol dengan baik.

Meiner (2011) menyatakan bahwa sehat dan sakit dipengaruhi oleh budaya, keluarga, sosial ekonomi dan lingkungan. Pengaruh keluarga terhadap sehat dan sakit berkaitan dengan peran dan fungsi keluarga. Keluarga memainkan peran yang sangat signifikan terhadap kehidupan keluarga yang lain terutama status sehat sakit.

Peran keluarga terdiri dari peran formal dan peran informal. Dalam peran informal keluarga terdapat peran merawat keluarga dan peran memotivasi/ pendorong keluarga (Friedman, 2010). Dimana merupakan tugas setiap anggota keluarga merawat anggota keluarga lain yang sakit sebagai fungsi pokok keluarga secara asuh yaitu memenuhi kebutuhan, pemeliharaan dan perawatan anggota keluarga yang sakit serta memenuhi kebutuhannya (Effendi, 1998).

Keluarga merupakan sistem pendukung utama yang memberi perawatan langsung pada setiap keadaan sehat dan sakit pasien keluarga mempunyai kemampuan untuk mengatasi masalah akan dapat menekan perilaku maladaptive (pencegahan sekunder) dan memulihkan perilaku adaptif (pencegahan tertier) sehingga derajat kesehatan pasien dan keluarga dapat ditingkatkan secara optimal (Keilat, 1992).

Berdasarkan wawancara yang dilakukan peneliti pada bulan Desember 
2012 dengan sepuluh orang keluarga dengan masalah anggota keluarga menderita diabetes melitus yang datang berkunjung ke Puskesmas Pauh Padang, tiga orang keluarga mengatakan bahwa tidak mengetahui perawatan pada pasien diabetes melitus, lima orang keluarga mengatakan bahwa mengetahui perawatan pada pasien diabetes melitus tetapi mereka tidak melakukan perawatan pada pasien dengan alasan yang berbagai macam dan dua orang keluarga mengatakan mengetahui perawatan pasien diabetes melitus dan melakukan perawatan pada pasien diabetes mellitus. Dari sepuluh orang penderita diabetes melitus, tujuh orang diantaranya mengatakan kurang mendapatkan perawatan dan motivasi dari keluarga dengan penyakit diabetes melitus yang dialami.

Berdasarkan fenomena diatas, maka peneliti tertarik untuk mengetahui tentang hubungan peran keluarga dengan pengendalian kadar gula darah pada pasien diabetes melitus di wilayah kerja puskesmas pauh padang tahun 2013.

\section{METODE}

Penelitian dilakukan pada bulan November 2012 sampai April 2013. Pengumpulan data diambil dengan memberikan kuesioner peran keluarga dan pemeriksaan kadar gula darah sewaktu yang dilakukan peneliti. Bentuk kuesioner menggunaksn check list yang dibuat peneliti sendiri.kuesioner terdiri dari dari dua jenis yaitu data demografi, kuesioner peran keluarga. Data diambl dalam satu waktu dengan pengisian kuesiomer dan pemeriksaan kadar gula darah.

Pengumpulan data awal dilakukan dengan mengumpulkan data dari buku sumber dan dari instansi terkait seperti puskesmas untuk mendapatkan jumlah responden yang akan diteliti. Kemudian setelah data didapatkan, selanjutnya dilakukan pengumpulan data langsung kepada responden. Data akan didapat melalui kuesioner, sebelum memberikan kuesioner, diberikan informed consent terlebih dahulu sebagai bentuk persetujuan untuk menjadi responden. Setelah itu dilakukan pengisian kuesioner dan pemeriksaan kadar gula darah. Data yang didapat yaitu peran keluarga yang terdiri dari peran keluarga merawat dan memotivasi. Setelah semua data terkumpul, dilakukan analisa data untuk mendapatkan hasil yang diteliti.

Setelah data dikumpulkan, langkah selanjutnya adalah melakukan pengolahan data, yaitu editing (pengolahan data), coding (pengkodean), entry (pemasukan data), dan cleaning (pembersihan data). Kemudian dilakukan analisa data untuk mengetahui distribusi frekuensi masingmasing variabel dan mengetahui hubungan antara variabel dependen dan variabel independen.

\section{HASIL DAN PEMBAHASAN}

\section{Berdasarkan hasil penelitian} didapatkan karakteristik responden berdasarkan jenis kelamin perempuan lebih besar yaitu $67 \quad(74,4 \%)$ dibandingkan dengan jenis kelamin laki-laki 23 (25,6\%). Berdasarkan klasifikasi umur responden didapatkan yang tertinggi rentang umur 1725 tahun yaitu $34(37,8 \%)$ dan yang terendah rentang umur 55-65 tahun yaitu 7 $(7,8 \%)$. Berdasarkan pendidikan yang terbanyak tamatan SLTA $40(44,4 \%)$ dan yang paling sedikit tamatan SD 9 (10\%). Berdasarkan pekerjaan didapatkan tbelum bekerja yaitu 19 (21,1\%), dan bekerja sebagai wiraswasta dan PNS/ABRI/POLRI yaitu $12,2 \%$. 
Tabel 1. Hubungan Peran Keluarga dengan Pengendalian Kadar Gula Darah pada Pasien Diabetes Melitus di Wilayah Kerja Puskesmas Pauh Padang Tahun 2013

\begin{tabular}{|l|c|c|c|c|c|c|}
\hline \multirow{3}{*}{$\begin{array}{c}\text { Peran } \\
\text { Keluarga }\end{array}$} & \multicolumn{3}{|c|}{ Pengendalian Kadar Gula Darah } & \multicolumn{2}{c|}{ Total } \\
\cline { 2 - 7 } & \multicolumn{2}{|c|}{$\begin{array}{c}\text { Tidak } \\
\text { Terkendali }\end{array}$} & \multicolumn{2}{c|}{ Terkendali } & N & $\%$ \\
\cline { 2 - 7 } & F & $\%$ & f & $\%$ & & \\
\hline Kurang Baik & 42 & 87,5 & 6 & 12,5 & 48 & 100 \\
Baik & 10 & 23,8 & 32 & 76,2 & 42 & 100 \\
\hline Jumlah & 52 & 57,8 & 38 & 42,2 & 90 & 100 \\
\hline
\end{tabular}

\section{Hubungan Peran Keluarga dengan Pengendalian Kadar Gula Darah Pada Pasien Diabetes Melitus}

Pada penelitian terlihat bahwa dari 90 keluarga terdapat 48 keluarga memiliki peran keluarga kurang baik dimana 42 $(87,5 \%)$ pasien diabetes melitus memiliki gula darah tidak terkendali. Namun masih ada $6(12,5 \%)$ pasien diabetes melitus memiliki gula darah terkendali. Sedangkan 42 keluarga memiliki peran baik terdapat $32(76,2 \%)$ pasien diabetes melitus memiliki gula darah terkendali dan 10 $(23,8 \%)$ pasien diabetes melitus memiliki gula darah tidak terkendali. Berdasarkan uji statistik Chi Square didapatkan nilai $p$ 0,000 dimana $p<0,05$ ini menunjukkan adanya hubungan yang bermakna antara Peran keluarga dengan pengendalian kadar gula darah pada pasien diabetes melitus.

Menurut Waspandji (2009) mengatakan bahwa pengawasan dan pemantauan dalam penatalaksanaan DM pada setiap saat menjadi penting. Dimana peran dari keluarga diperlukan khususnya dalam pengontrolan dan pengendalian kadar gula darah pada penderita DM. Hal ini sejalan dengan pernyataan Asdie (2000) keberhasilan penatalaksaan DM ditentukan peranan aktif dari keluarga dalam pengontrolan kadar gula darah, pencegahan komplikasi akut maupun kronik.

Analisa peneliti berdasarkan hal diatas, keluarga yang memiliki peran baik, maka terkendali gula darah pada pasien diabetes melitus. Hal ini sejalan dengan hasil penelitian pada tabel 6 didapatkan keluarga yang memiliki peran keluarga baik lebih tinggi $(76,2 \%)$ pasien diabetes melitus memiliki gula darah terkendali dari pada $(23,8 \%)$ pasien diabetes melitus memiliki gula darah tidak terkendali. Dimana didukung oleh Valery (2004) keluarga merupakan peran utama dalam pemeliharaan kesehatan dan membantu pasien dalam perawatan dan pengendalian diabetes melitus, memberikan semangat dan motivasi pada pasien, agar melanjutkan hidupnya, meyakinkan pasien bahwa mereka juga bagian penting, dibutuhkan dan dinginkan dalam keluarga, meyakinkan bahwa banyak orang yang berhasil mengontrol kadar gula darah kemudian melakukan aktivitas normal.

Association (2006) mengatakan bahwa perencanaan pengelolaan diabetes melitus harus dilakukan secara bersama antara pasien dengan keluarga agar kadar gula darah dapat terkontrol. Dalam perawatan pasien diabetes melitus diperlukan peranan keluarga dalam mengelola anggota keluarganya (Waspandji, 2009).

Para ahli mengatakan bahwa pasien diabetes mellitus harus mampu mengendalikan kadar gula darah dalam keadaan normal (Levy, 2008). Hal ini sejalan dengan pernyataan Waspandji 
(2005) bahwa sampai saat ini penyakit DM tidak dapat disembuhkan, tetapi dapat dikontrol dengan mengatur kadar glukosa darah tetap normal. Dalam pengontrolan dan pengendalian kadar gula darah keluarga memiliki peran yang penting.

Diabetes melitus bila tidak ditangani dengan baik akan mengakibatkan komplikasi pada berbagai organ tubuh seperti mata, ginjal, jantung, pembuluh kaki, syaraf dan lain-lain. maka itu sebelum terjadi komplikasi yang lebih lanjut, maka pengobatan dan penatalaksanaan pada pasien diabetes melitus harus dilakukan. Peran keluarga sangat dibutuhkan untuk mencapai kesehatan yang maksimal, untuk mencapai tujuan hidup sehat keikutsertaan pasien dan keluarga dalam mengelola penatalaksanaan kadar gula darah menjadi sangat penting agar gula darah pasien terkendali (Rifki, 2009).

Keluarga sebagai suatu kelompok dapat menimbulkan, mencegah, mengabaikan atau memperbaiki masalahmasalah kesehatan keluarga itu sendiri, hampir tiap masalah kesehatan mulai dari awal sampai ke penyelesaian akan dipengaruhi oleh keluarga. Keluarga mempunyai peran utama dalam perawatan kesehatan seluruh anggota keluarga dan bukan individu sendiri yang mengusahakan tercapainya tingkat kesehatan yang diiinginkan (Friedman, 2010).

Menurut Effendi, 1998 peran dan tugas setiap anggota keluarga merawat anggota keluarga yang sakit sebagai fungsi pokok keluarga secara asuh yaitu memnuhi kebutuhan dan pemeliharaan dan perawatan anggota keluarga yang sakit serta memenuhi kebutuhannya. Hal ini sejalan pendapat Rifki (2010) keluarga dengan anggota keluarga yang menderita diabetes melitus sudah tentu memerlukan perawatan terhadap dampak-dampak penyakit diabetes melitus yang menimbulkan ketidakmampuan pada pemenuhan kebutuhan pada individu. Peran dan tugas keluarga yang diharapkan adalah membantu dalam memberikan perawatan dan pengendalian pada pasien diabetes melitus

Menurut Friedman (2010) peran merupakan serangkaian perilaku yang diharapkan pada seseorang sesuai dengan posisi sosial yang diberikan baik secara formal maupun secara informal. Dalam peran secara informal terdapat peran keluarga merawat dan peran keluarga memotivasi.pada penelitian didapatkan peran keluarga yang paling rendah didapatkan yaitu peran keluarga merawat. Peran keluarga dalam merawat diantaranya mengenal masalah, mengambil keputusan, merawat anggota keluarga, memodifikasi lingkungan dan memanfaatkan lingkungan. Pada penelitian didapatkan peran keluarga dalam merawat yang tertinggi yaitu dalam mengenal masalah. Hal ini bisa dikaitkan dengan karakteristik responden : pendidikan yaitu lebih dari separuh $(60 \%)$ memiliki pendidikan menengah atas. Semakin tinggi pendidikan seseorang, maka semakin mudah menerima pengetahuan baru. Pendidikan merupakan salah satu faktor yang mempengaruhi peran karena makin tinggi pendidikan seseorang maka makin mudah untuk menerima informasi sehingga makin banyak pengetahuan yang dimiliki (Roshsismandoko dan Endang, 2003).

Analisa peneliti, peran keluarga yang kurang baik ini disebabkan karena ketidaktahuan keluarga tentang bagaimana peran yang seharusnya dilakukan oleh keluarga dalam memberikan perawatan pada pasien diabetes melitus dimana berdasarkan identifikasi terhadap jawaban kuesioner pada kuesioner peran keluarga dalam merawat yaitu keluarga tidak membedakan makanan untuk pasien diabetes melitus dengan anggota keluarga lainnya seperti gula rendah kalori $(78,8 \%)$. Sedangkan keluarga yang mempunyai peran keluarga baik dalam pada pasien diabetes melitus dirumah karena keluarga mampu mengenal masalah kesehatan pasien diabetes melitus yaitu keluarga mengetahui

cara pengontrolan/pengendalian kadar gula 
darah pada pasien diabetes melitus $(89,3 \%)$.

Berdasarkan penelitian pada keluarga yang memiliki peran keluarga kurang baik masih terdapat pasien diabetes melitus memiliki gula darah terkendali. Hal ini didapatkan pada pasien diabetes melitus yang sadar akan pentingnya kesehatan, dimana pasien menjaga pola makan, minum obat teratur dan melakukan olahraga secara teratur. Sedangkan pada keluarga yang memiliki peran keluarga baik masih terdapat pasien diabetes melitus memiliki gula darah tidak terkendali. Hal ini didapatkan pada pasien yang mengganggap penyakitnya merupakan penyakit seumur hidup yang tidak dapat disembuhkan dan penyakit turun temurun yang biasa di temui di masyarakat.

\section{KESIMPULAN DAN SARAN}

Dari hasil univariat dan bivariat diatas dapat disimpulkan bahwa peran keluarga dengan kategori kurang baik pada pasien diabetes melitus di wilayah kerja Puskesmas Pauh Padang tahun 2013 adalah sebanyak 48 (53,3\%), pengendalian kadar gula darah dengan kategori tidak terkendali adalah sebanyak 52 orang $(57,8 \%)$, dan terdapat hubungan yang bermakna antara peran keluarga dengan pengendalian kadar gula darah pada pasien diabetes melitus di wilayah kerja Puskesmas Pauh Padang tahun 2013.

Diharapkan kepada pimpinan puskesmas untuk memberikan penyuluhan kepada keluarga tentang pentingnya peran serta keluarga dalam pengendalian kadar gula darah pada pasien diabetes melitus. Adanya peran keluarga dalam pengendalian kadar gula darah akan memberikan perawatan dan motivasi kepada anggota keluarga yang menderita diabetes melitus untuk tetap mengendalikan kadar gula darah.

\section{DAFTAR PUSTAKA}

1. Alimul, A. (2001). Riset Keperawatan dan Tehnik Penulisan Ilmiah. Jakarta : Salemba Medika

2. Arikunto, S. (2002). Prosedur penelitian suatu pendekatan praktek, esidi 5. Jakarta: Rineka Cipta

3. Asdie, A.H. (2000). Patogenesis dan terapi diabetes melitus tipe 2, edisi pertama. Yogyakarta: Medika Fakultas Kedokteran Universitas Gadjah Mada

4. Association, D, A. (2006). Standars of Medical Care in Diabetes, Diabetes Care. 2006: 29, S4-42.

5. Aurora, A. (2008). 5 langkah mencegah dan mengobati diabetes. Jakarta: PT Bhuana Ilmu Populer.

6. Bailon dan Maglaya. (1999). Konsep keluarga. Diakses pada hari Senin 31 Desember 2012 pukul 10.00 dari http://id.shvoong.com/books/1896185. konsep-keluarga.
7. Budiarto, E, (2002). Biostatistika untuk kedokteran dan kesehatan masyarakat. Jakarta: EGC.

8. Cipta, A.A. (2002). Riset keperawatan dan teknik penulisah ilmiah. Jakarta : Salemba Medika.

9. Dalimarta, S. (2002). Ramuan tradisional untuk pengobatan diabetes melitus. Jakarta : Swadaya.

10. Darmono, J. 2005. Pengaturan Pola Hidup Penderita Diabetes untuk Mencegah Komplikasi Kerusakan Organ-organ Tubuh. Jakarta: Erlangga.

11. Dinas Kesehatan Kota Padang. (2012). Data penyakit tahun 2011 kota Padang: Dinkes Padang.

12. Effendi, N. (1998). Dasar-dasar keperawatan kesehatan masyarakat, edisi 2. Jakarta : EGC.

13. Friedman, M. (2010). Keperawatan keluarga : Teori dan Praktik edisi 5. Jakarta : EGC. 
14. Harmoko. ( 2012). Asuhan keperawatan keluarga. Yogyakarta : Pustaka Pelajar

15. Hidayat, A. A. (2008). Metode penelitian keperawatan dan teknik analisis data. Jakarta : Salemba Medika.

16. Isworo, A. (2010). Hubungan dukungan keluarga terhadap kadar gula darah pada pasien DM tipe 2 di RSUD Stagen. Jurnal keperatan sudirman, Volume 5, no 1

17. Keliat, B. A. (1999). Proses keperawatan kesehatan jiwa Edisi 2. Jakarta : EGC

18. Kosasi, S. M. (2011) hubungan peran keluarga dalam merawat dan memotivasi penderita pasca stroke dengan kepatuhan penderita mengikuti rehabilitasi. Skripsi Unand .

19. Lanywati, E. 2011. Diabetes melitus penyakit kencing manis. Yogyakarta : Konisius

20. Levy, D. Dr. (2008). Blood glucose levels in type 2 diabetes how low is good or bad for you. Diakses pada tanggal 29 Januari 2010 dari : http://www.professionals.londomedical .co.uk/..Blood\%20glucose\%20levels\% 20in\%20Type\%20\%20diabetes\%20

21. Mansjoer, A. (2000). Kapita selekta kedokteran. Jakarta: Media Aesculapius.

22. Notoatmodjo, S. (2005). Metodologi penelitian kesehatan. Jakarta : Rineka Cipta

23. Nursalam. (2008). Konsep dan penerapan metodologi penelitian keperawatan Edisi 2. Jakarta: Salemba Medika

24. PERKENI. (2002). Konsensus pengolahan diabetes melitus tipe 2 di Indonesia. Jakarta: PB. PERKENI.

25. Potter, P. A \& Perry A. G. (2005). Fundamental keperawatan volume 1. Jakarta : EGC

26. Potts, N.L., \& Mandleco,. B.L. (2007). Pediatric nursing: caring for children and their families. Clinton Park, New York: Thomson Delmar Learning.
27. Rifki, N. (2009). Penatalaksanaan diabetes dengan pendekatan keluarga, dalam penatalaksanaan diabetes melitus terpadu, edisi kelima. Jakarta: FK UI.

28. Sarwono, S. (1997). Psikologi remaja. Jakarta : PT. Raja Grafindo Persada

29. Setiadi. (2008). Konsep dan proses keperawatan keluarga. Yogyakarta : Graha Ilmu

30. Smeltzer, S. \& Bare. (2008). Brunner \& suddarth's textbook of medical surgical nursing. Philadelpia : Lippincott

31. Soegondo, S. (2009). Prinsip pengobatan diabetes, insulin dan obat hipoglikemik, dalam penatalaksanaan diabetes melitus terpadu, edisi kelima. Jakarta: FK UI.

32. Soegondo, S. (2009). Diagnosis dan klasifikasi diabetes melitus terkini, dalam penatalaksanaan diabetes melitus terpadu, edisi kelima. Jakarta: FK UI.

33. Soewondo, P. (2009). Pemantauan Pengendalian diabetes melitus, dalam penatalaksanaan diabetes melitus terpadu, edisi kelima. Jakarta: FK UI.

34. Sustrani, L., Alam, S. \& Hadibroto, I. (2006). Diabetes. Jakarta: PT.. Gramedia Pustaka Utama.

35. Suyono, S. (2009). Patologis diabetes melitus dalam penatalaksanaan diabetes melitus terpadu, edisi kelima. Jakarta: FK UI.

36. Tjokroprawiro, A. 2001. Diabetes Melitus Klasifikasi, Diagnosis, dan Terapi, Edisi ketiga. Jakarta : PT. Gramedia Pustaka Utama

37. Triyono, H (2009). Agar gula darah tetap rendah. Diakses pada tanggal 11 September 2009 dari : http://www.tempointeraktif.com/hg/ke sehatan/2009/07/21/brk.200910721118151.html

38. Waspadji, S. (2005). Mekanisme dasar dan pengelolaannya yang rasional, dalam penatalaksanaan diabetes terpadu, edisi kelima. Jakarta: FK UI. 
39. WHO. (2006). Defenition and diagnosis of diabetes melitus and intermediate hyperglikemia. $\mathrm{WHO}$

Library catalaguing in publication data 